\title{
Variation in the Hexanic Extract Composition of Lippia graveolens in an Arid Zone from Mexico: Environmental Influence or True Chemotypes?
}

\author{
Tzasna Hernández, ${ }^{\mathrm{a}, *}$, Margarita Canales ${ }^{\mathrm{a}}$, Angel Duran ${ }^{\mathrm{a}}$, Ana María García ${ }^{\mathrm{a}}$, José Guillermo Avila , \\ Luís Hernández-Portilla ${ }^{\mathrm{b}}$, Martha Alvarado ${ }^{\mathrm{a}}$, Marisol Romero ${ }^{\mathrm{a}}$, Bárbara Terán ${ }^{\mathrm{a}}$, Patricia Dávila ${ }^{\mathrm{c}}$ and \\ Rafael Lira ${ }^{\mathrm{c}}$
}

\author{
${ }^{a}$ Laboratorio de Fitoquímica, UBIPRO, Facultad de Estudios Superiores-Iztacala, Universidad Nacional Autónoma de \\ México, Tlalnepantla 54090, Edo. de Mexico, Mexico \\ ${ }^{b}$ Laboratorio de Fisiología Vegetal UBIPRO, Facultad de Estudios Superiores-Iztacala, Universidad Nacional \\ Autónoma de México, Tlalnepantla 54090, Edo. de Mexico, Mexico \\ ${ }^{c}$ Laboratorio de Recursos Naturales, UBIPRO, Facultad de Estudios Superiores-Iztacala, Universidad Nacional \\ Autónoma de México, Tlalnepantla 54090, Edo. de Mexico, Mexico
}

\begin{abstract}
The hexanic extract composition of two populations of Lippia graveolens growing in an arid zone in the Tehuacán-Cuicatlán Valley (Zapotitlán Salinas, Puebla), Central Mexico, in different seasons of the year, and in contrasting conditions of ecological disturbance has been studied by GC and GC-MS. Regarding to the composition of these extracts, qualitative differences among the two populations were found. Thus, 9 compounds were identified from the extracts of the Zone A (the less disturbed) and 10 from the ones of Zone B (the most disturbed). Thymol was detected as the major compound in most of the individuals sampled, while at the season level, September was the more productive month for zone B (higher content of identified compounds) and the only one that presents antibacterial activity. Lippia graveolens displays quantitative and qualitative variations both within and between natural plant populations.
\end{abstract}

Key Words: Arid zones, Lippia graveolens, Thymol, Zapotitlán Salinas.

\section{INTRODUCTION}

In a recent study on the phytochemical basis of the traditional knowledge on the plants used for the treatment of gastrointestinal infectious diseases in traditional medicine from Zapotitlán Salinas, Lippia graveolens was one of the most important and effective plants for those purposes [1]. In addition, the study also identified that some of the most important compounds responsible for that effectiveness were thymol and carvacrol. It is widely known, however, that the production of this kind of secondary metabolites could be determined by climatic factors, season of the year and/or the development stage of the plant [2-5].

Considering the above mentioned, the objective of this work was to determine, in different seasons of the year, and for contrasting conditions of ecological disturbance, the antibacterial activity and the existence of inter and intra population variation in the composition of the hexanic extracts of Lippia graveolens populations growing in an arid zone in the Tehuacán-Cuicatlán Valley in Central Mexico. The final goal was to determine if this variation could potentially be recognized as chemotypes deserving attention for their conservation in a seed bank. For the purposes of this paper, a chemotype (sometimes called chemovar) is a chemically

\footnotetext{
*Address correspondence to this author at the Tzasna Hernández. Laboratorio de Fitoquímica, UBIPRO, Facultad de Estudios Superiores-Iztacala, Universidad Nacional Autónoma de México, Tlalnepantla 54090, Edo. de Mexico, México; Tel: + 52-5-623-11-36; Fax: + 52-5-623-12-25;

E-mail: tzasna@servidor.unam.mx
}

distinct entity in a plant or microorganism, with differences in the composition of the secondary metabolites $[4,6]$.

\section{STUDY SITE}

Zapotitlan Salinas is a small village located within the limits of the Tehuacán Cuicatlán Biosphere Reserve in central Mexico. Zapotitlán Salinas is located in the southeastern part of the Valley of Tehuacán-Cuicatlán, in the State of Puebla (Fig. 1). The climate is arid with a mean annual rainfall of $542.5 \mathrm{~mm}$ and annual temperature of $19.8^{\circ} \mathrm{C}$ [7]. According to the classification proposed by Rzedowski (1978) [8], there are three general vegetation types in the zone, namely, arid tropical shrubland, thorn forest and tropical deciduous forest, with thorn-scrub as the predominant vegetation. Mediterranean type vegetation commonly called "mexical" or chaparral is also present, covering hills up to $2000 \mathrm{~m}$ [9]. The Chocho-Popoloca is the dominant ethnic group in the region $[1,10,11]$.

\section{EXPERIMENTAL}

\section{Field Work}

\section{Plant Material}

Between May 2005 and March 2006 the samples were collected in the Terrazas Aluviales, in Zapotitlán Salinas, Puebla (central Mexico) in two places under clearly contrasting disturbed conditions (named Zones A and B). Zone A, known as Las Granjas, corresponds to the less disturbed condition (continuous cover of vegetation, soil primary structure with a well defined superficial horizons), whereas 


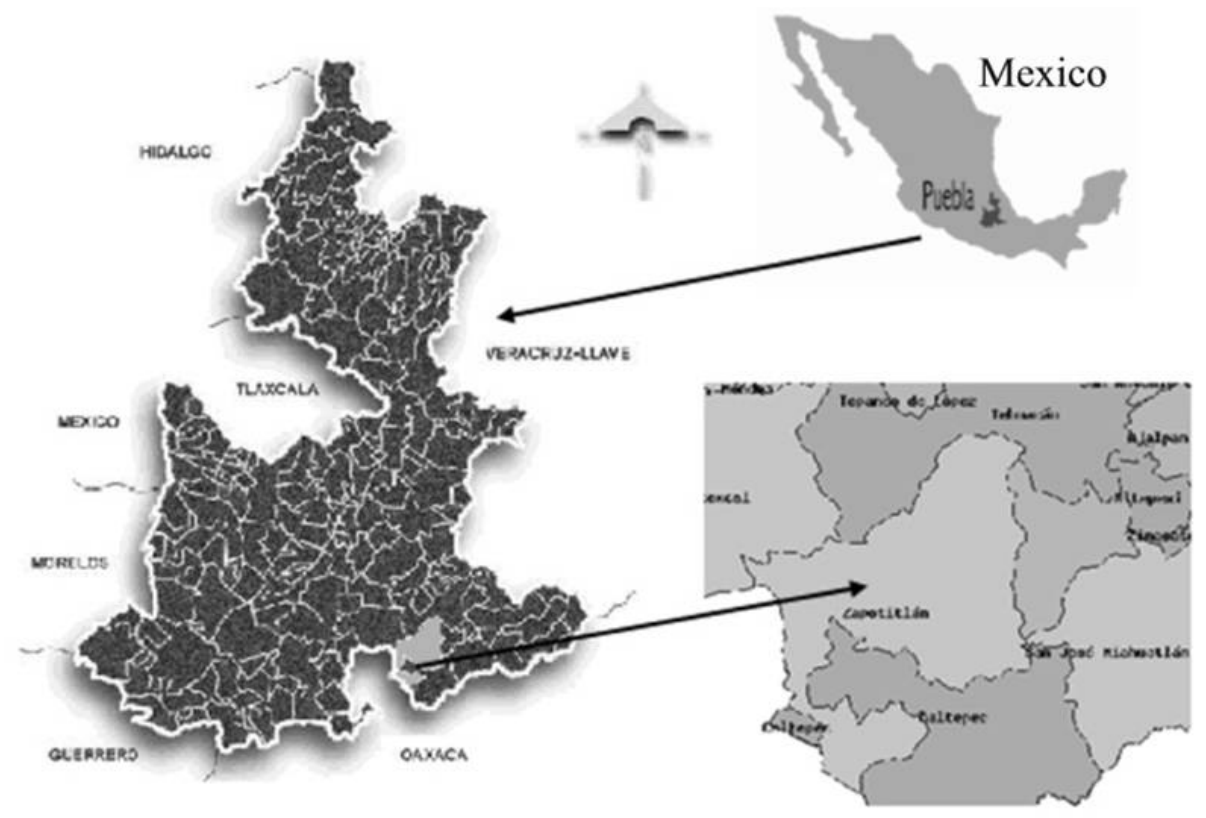

Fig. (1). Geographic position of Zapotitlan Salinas, Puebla (Mexico).

zone B is the most disturbed (discontinuous cover of vegetation, soil with maximum fragmentation, geological outcrops, clayed sediments derived from shale and limestone, and the relieve has cavities and depressions by erosion); this zone is placed bordering to Zapotitlán's Botanical Garden [12]. Samples were obtained. Voucher specimens of all collection are in the Natural Resources Laboratory of the Facultad de Estudios Superiores Iztacala, Universidad Nacional Autónoma de México.

A total of four field expeditions were done during this period. Three of them in dry season (May and December 2005 and March 2006), and the other one towards final part of rain season in the first year (September 2005). For the zone B was possible to collect in all the seasons, while for the zone A the collections only could be undertaken in December 2005 and March 2006. Twenty individuals were collected in the zone A and 21 in the zone B. In all the cases, samples of $10 \mathrm{~g}$ of aerial parts were taken. A total of 124 samples were included in the study. In order to detect differences in the secondary metabolites production that could confirm the existence of true chemotypes or simply being product of the effect of environmental conditions, all the individuals were labeled and georeferenced with the purpose of re-collect them without difficulty in the following seasons.

\section{Laboratory Work}

\section{Preparation of the Extracts}

Fresh aerial part (10 g) of each sample was extracted with hexane (seven days). The extracts were filtered, successively concentrated (the solvent was completely evaporated) at room temperature and kept in dark at $4{ }^{\circ} \mathrm{C}$ until tested.

Gas Chromatography (GC), Gas Chromatography - Mass Spectrometry (GC-MS) Analysis Conditions

The determination of the compounds present in those extracts was performed using a Hewlett Packard 5890-II GC
(Hewlwtt-Packard, Wilmington, DE USA) equipped with a DB WAX column (25 m x $0.25 \mathrm{~mm}$; film thickness, 0.33 $\mu \mathrm{m})$. The temperature of the column was programmed from $80{ }^{\circ} \mathrm{C}$ to $220{ }^{\circ} \mathrm{C}$ at $8{ }^{\circ} \mathrm{C} / \mathrm{min}$. The injector and detector temperatures were $225^{\circ} \mathrm{C}$. The gas carrier was He, at a flow rate of $1 \mathrm{ml} / \mathrm{min}$. Peak areas were measured by electronic integration. The relative amount of the individual components was based on the peak areas. GC-MS analysis was performed on a Jeol AX505H using a DB Wax (25 m x $0.25 \mathrm{~mm}, 0.33 \mu \mathrm{m})$ capillary column. The temperature of the column and the injector were the same as those from GC. Mass spectra were recorded at $70 \mathrm{eV}$. $1 \mu \mathrm{L}$ of samples was injected manually. The components were identified by comparison of their retention indices and mass spectra with the NIST/EPA/NIH Mass Spectral Library.

\section{Antibacterial Activity}

Antibacterial activity was evaluated by triplicate in each sample from the two collection zones. This evaluation was performed using the Kirby-Bauer method [13]. The bacterial strains tested were Sarcina lutea (Gram positive) and Vibrio cholerae No 01 (Gram negative). Sensidiscs were impregnated with $2 \mathrm{mg}$ of hexanic extract. Positive and negative controls were chloramphenicol $(25 \mu \mathrm{g})$ and hexane $(10 \mu \mathrm{L})$ sensidiscs, respectively.

\section{Statistical Analysis}

The data obtained form the extracts of each collection site and season, were analyzed by multivariate methods (principal components), using NTSYS version 2.0 [14], to detect the variation in the concentration and composition of the secondary metabolites in the populations and reveal some of the plants as potentially chemotypes carriers, these analysis were done for each collection site and season. Additionally, in order to define inter and intra population differences, 
an analysis of variance (multifactor ANOVA) of the average values of the compounds obtained was done. p-values of 0.001 or less were considered statistically significant. This analysis was performed by using the Statistics software version 6.0 .

\section{RESULTS AND DISCUSSION}

Hexanic extracts were prepared from the samples obtained at the different collection sites and seasons. Regarding to the composition of these extracts, qualitative differences among the two populations were found. Thus, 9 compounds were identified from the extracts of the Zone A and 10 from the ones of Zone B. The compounds identified were: 3-Carene, $\alpha$-Pinene, $\rho$-Cymene, Carvacrol, Thymol, Isocaryophyllene ( $\gamma$-caryophyllene), $\alpha$-Humulene, Guaia1(5), 7(11)-diene, Thymol methyl ether in both zones and $\alpha$ Thujene was present only in zone B (Tables 1 and 2) which suggest the possibility that more secondary metabolites are produced in disturbed zones [15].

The hexane extracts were characterized by high percentages of monoterpenes, especially oxygenated ones (Thymol methyl ether, Carvacrol, Thymol) as well as alkyl-

Table 1. Statistics Parameters of Lippia graveolens Hexane Extracts from Zone A (Las Granjas)

\begin{tabular}{|c|c|c|c|c|c|c|c|}
\hline $\mathbf{C}$ & RT & $\operatorname{Mean}(\%)$ & Min & Max & $\operatorname{Mean}(\%)$ & Min & $\operatorname{Max}$ \\
\hline$\alpha$-Pinene & 4.73 & $0.11 \pm 0.16$ & 0 & 0.32 & 0 & 0 & 0 \\
\hline$\rho$-Cymene & 5.27 & $3.77 \pm 2.84$ & 0.51 & 12.57 & $4.00 \pm 3.48$ & 0 & 13.20 \\
\hline Thymol methyl ether & 9.02 & 0 & 0 & 0 & $0.33 \pm 0.58$ & 0 & 1.83 \\
\hline Carvacrol & 10.10 & $0.03 \pm 0.88$ & 0 & 0.52 & $0.88 \pm 3.11$ & 0 & 13.53 \\
\hline Thymol & 10.31 & $21.60 \pm 17.11$ & 2.82 & 80.29 & $11.11 \pm 11.23$ & 0 & 35.97 \\
\hline Isocaryophyllene & 12.37 & $0.41 \pm 0.32$ & 0 & 0.64 & $0.10 \pm 0.28$ & 0 & 1.11 \\
\hline
\end{tabular}

C, Compound; RT, Retention Time, $\mathrm{n}=20$ individuals.

Table 2. Statistics Parameters of Lippia graveolens Hexane Extracts from Zone B (Jardín Botánico)

\begin{tabular}{|c|c|c|c|c|c|c|c|c|c|c|c|c|c|}
\hline \multirow[t]{2}{*}{ C } & \multirow[t]{2}{*}{ RT } & \multicolumn{3}{|c|}{ May 2005} & \multicolumn{3}{|c|}{ September 2005} & \multicolumn{3}{|c|}{ December 2005} & \multicolumn{3}{|c|}{ March 2006} \\
\hline & & Mean $(\%)$ & Min & $\operatorname{Max}$ & Mean (\%) & Min & $\operatorname{Max}$ & Mean (\%) & Min & $\operatorname{Max}$ & Mean (\%) & Min & $\operatorname{Max}$ \\
\hline$\alpha$-Thujene & 3.86 & $0.002 \pm 0.21$ & 0 & 0.04 & $0.54 \pm 0.97$ & 0 & 4.02 & $0.003 \pm 0.01$ & 0 & 0.06 & 0 & 0 & 0 \\
\hline$\alpha$-Pinene & 4.73 & $0.06 \pm 0.10$ & 0 & 0.29 & $0.81 \pm 1.02$ & 0 & 4.75 & $0.09 \pm 0.13$ & 0 & 0.58 & $0.02 \pm 0.11$ & 0 & 0.52 \\
\hline 3-Carene & 5.90 & $0.49 \pm 0.64$ & 0 & 2.26 & $2.58 \pm 1.95$ & 0 & 5.51 & $0.43 \pm 0.33$ & 0 & 1.34 & $0.07 \pm 0.17$ & 0 & 0.55 \\
\hline $\begin{array}{c}\text { Thymol } \\
\text { methyl ether }\end{array}$ & 9.02 & $1.31 \pm 1.66$ & 0 & 5.89 & $2.02 \pm 2.28$ & 0 & 7.32 & $0.28 \pm 0.57$ & 0 & 1.92 & $0.30 \pm 0.43$ & 0 & 0.43 \\
\hline Carvacrol & 10.10 & $0.41 \pm 0.68$ & 0 & 2.02 & $1.00 \pm 1.94$ & 0 & 6.50 & $0.27 \pm 0.55$ & 0 & 2.01 & $1.41 \pm 3.17$ & 0 & 12.96 \\
\hline $\begin{array}{l}\text { Guaia-1(5), } 7 \\
\text { (11)-diene }\end{array}$ & 12.93 & $0.20 \pm 0.38$ & 0 & 1.28 & $0.92 \pm 0.84$ & 0 & 1.97 & $0.07 \pm 0.13$ & 0 & 0.49 & 0 & 0 & 0 \\
\hline
\end{tabular}

C, Compound; RT, Retention Time, $\mathrm{n}=21$ individuals. 
monoterpenes ( $\alpha$-Thujene, $\alpha$-Pinene, $\rho$-Cymene, 3-Carene) and some sesquiterpenes (Isocaryophyllene, $\alpha$-Humulene, Guaia-1(5), 7(11)-diene). In all sites and seasons, the oxygenated monoterpenes were present in higher percentages than monoterpenes hydrocarbons. Thymol was detected as the major compound in most of the individuals sampled, while at the season level, September was the more productive month.

The results of the multifactor ANOVA analysis revealed significant differences in the concentration and composition of the identified substances for the different sampling seasons within each zone (seasonal variation). In the only case where a comparison among the two populations was possible (December 2005/March 2006 samples), the results revealed significant differences within and among populations in the concentration and composition of most of the identified compounds (inter-population variation) (Table $\mathbf{3}$ ).
Multivariate analysis revealed intrapopulation variation in the two sites, which seems to be associated to the season, as well as to the quantitative differences in concentration of the identified metabolites (Tables 1 and 2; Figs. 2 and 3). As a consequence, it is difficult to identify individuals that could be recognized as outliers (and possible chemotypes carriers) respect to the rest of the population. The most common condition is that, in both sites and for the different seasons, almost any individual be found in different parts of the plot, or be included in the group with more individuals. Nevertheless, some exceptions to this pattern were documented for the two zones. Thus, for the Zone A, individuals 2, 10, 13, 14 and 20, were systematically placed as outliers in the two sampling seasons (Fig. 2). In the case of the zone B, individuals 5 and 8 , were always placed as outliers in the plot (Fig. 3), while individuals 2, 10 and 12 were also outliers at least in three of the seasons. Table 4 summarizes these results. These individuals should be more carefully

Table 3. Results of the Multifactor ANOVA Analysis ( $F$ and $P$ Values)

\begin{tabular}{|c|c|c|c|c|c|c|c|c|c|c|c|}
\hline \multicolumn{12}{|c|}{ Identified Compounds } \\
\hline & & $\alpha$-Thujene & $\alpha$-Pinene & $\rho$-Cymene & 3-Carene & $\begin{array}{c}\text { Thymol } \\
\text { methyl ether }\end{array}$ & Carvacrol & Thymol & Isocaryophyllene & $\alpha$-Humulene & $\begin{array}{l}\text { Guaia-1(5), } \\
\text { 7(11)-diene; }\end{array}$ \\
\hline \multirow[t]{2}{*}{$A$ and $B$ zone } & $\mathrm{F}$ & 0.95 & 0.06 & 1.19 & 0.52 & 1.43 & 0.61 & 2.64 & 0.20 & 1.0 & $4.78^{*}$ \\
\hline & $\mathrm{P}$ & 0.3324 & 0.8139 & 0.2770 & 0.4736 & 0.2361 & 0.4384 & 0.1083 & 0.6557 & 0.3216 & $0.0318^{*}$ \\
\hline \multirow{2}{*}{$\begin{array}{c}\text { Dec } 2005 \text { and } \\
\text { march } 2006\end{array}$} & $\mathrm{~F}$ & 0.95 & $12.15^{*}$ & 0.85 & $45.60^{*}$ & 2.95 & $4.03 *$ & $11.61^{*}$ & $15.54 *$ & 0.27 & $7.24 *$ \\
\hline & $\mathrm{P}$ & 0.3324 & $0.0081^{*}$ & 0.3583 & $0.001^{*}$ & 0.0901 & $0.0480 *$ & $0.0010^{*}$ & $0.0002 *$ & 0.6080 & $0.0087^{*}$ \\
\hline \multirow{2}{*}{$\begin{array}{c}\text { Zone/season } \\
\text { collection }\end{array}$} & $\mathrm{F}$ & 0.95 & 0.54 & 0.33 & 3.12 & 2.25 & 0.08 & 0.32 & 0.60 & 0.25 & $4.78^{*}$ \\
\hline & $\mathrm{P}$ & 0.3324 & 0.4637 & 0.5636 & 0.0809 & 0.1373 & 0.7769 & 0.5721 & 0.4400 & 0.6183 & $0.0318^{*}$ \\
\hline \multirow[t]{2}{*}{ Zone A } & $\mathrm{F}$ & - & $9.43^{*}$ & 0.05 & $26.26^{*}$ & $6.37 *$ & 1.50 & $5.25^{*}$ & $10.76^{*}$ & 0.25 & 1.00 \\
\hline & $\mathrm{P}$ & - & $0.0039 *$ & 0.8168 & $0.001^{*}$ & $0.0159 *$ & 0.2278 & $0.0276^{*}$ & $0.0022^{*}$ & 0.6206 & 0.3236 \\
\hline \multirow[t]{2}{*}{ Zone B } & $\mathrm{F}$ & $6.33 *$ & $10.87 *$ & $8.79 *$ & $24.53^{*}$ & $6.89 *$ & 1.14 & $13.50^{*}$ & $16.87^{*}$ & $3.07 *$ & $17.00^{*}$ \\
\hline & $\mathrm{P}$ & $0.0007 *$ & $0.001 *$ & $0.001^{*}$ & $0.001 *$ & $0.0004 *$ & 0.3369 & $0.001 *$ & $0.001 *$ & $0.0327 *$ & $0.001^{*}$ \\
\hline
\end{tabular}

*indicate significant differences; F, value reported in statistics tables; $\mathrm{P}$, calculated probability.
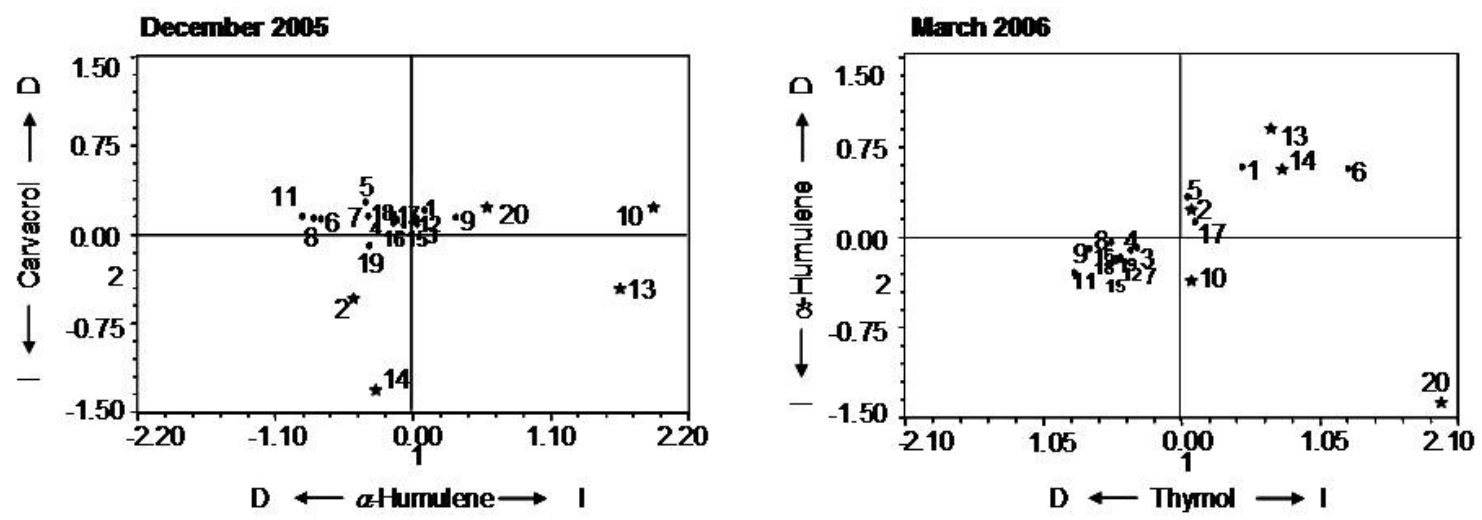

Fig. (2). Groups/Outliers identified in Zone A. I, increase; D, decrease; •, group; $\star$, outliers. 

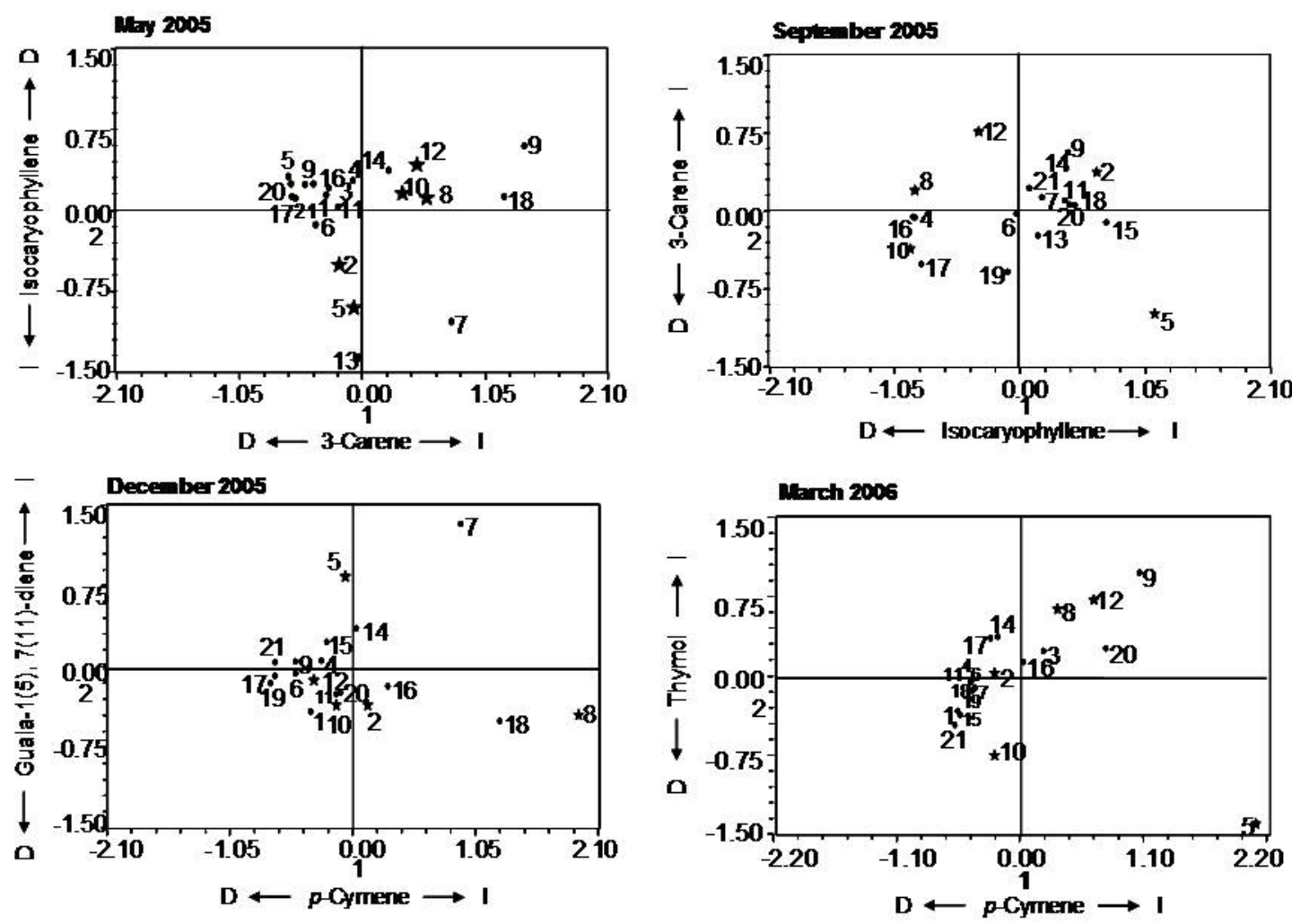

Fig. (3). Groups/Outliers identified in Zone B. I, increase; D, decrease; •, group; $\star$, outliers.

Table 4. Summary of Individuals Consistently Found as Outliers in Zones A and B

\begin{tabular}{|c|c|c|c|c|c|}
\hline \multicolumn{2}{|c|}{ Zone A } & \multicolumn{3}{c|}{ Zone B } \\
\hline Dec 2005 & March 2006 & May 2005 & Sept 2005 & Dec 2005 & 2 \\
\hline \hline 2 & & 2 & 2 & 10 & 13 \\
\hline 5 & 5 & 5 & 5 & 13 & 13 \\
\hline 8 & 10 & 8 & 10 & 20 & 14 \\
\hline 10 & 12 & & 12 & 20 \\
\hline
\end{tabular}

Each column represent the outliers (number of individual studied) of each season/zone.

studied in order to determinate if they can be recognized as true chemotypes.

Antibacterial activity was only found for the September samples from Zone B, which coincides with the season of major concentration of secondary metabolites ( $\alpha$-Pinene, $\rho$-Cymene, Thymol) (Table 5) which are already known to exhibit antibacterial activity [16-19], and the season when people collects the plant $[1,11]$. It is important to stand out that although in most of the samples thymol was present, antibacterial activity was only found for the September samples, this is due probably to antagonistic effects between some components that affect the antimicrobial activity for the hexanic extracts [20].
In conclusion, Lippia graveolens displays quantitative and qualitative variations within and between natural plant populations, which are expressed in response to the contrasting conditions of the two sites where they live. That is why the rare individuals (outliers in the analysis) are interesting for further study, since their chemical features could have a genetic basis more than an environmental one.

\section{ACKNOWLEDGEMENTS}

The authors are grateful to Martín Paredes, Rocío Rosas, Rocío Serrano, and Ariadna Aguilar for their technical assistance. This research has been supported by KEW Royal Botanical Gardens. 
Table 5. Antibacterial Activity of the Hexanic Extracts of Lippia graveolens Collected in Zone B (September 2005)

\begin{tabular}{|c|c|c|}
\hline \multirow{2}{*}{ Individual Number } & \multicolumn{2}{|c|}{ Inhibition Zone (mm) } \\
\hline & $S l$ & Vch No01 \\
\hline Positive Control & $32.00 \pm 0.50$ & $35.00 \pm 0.50$ \\
\hline 1 & nd & nd \\
\hline 2 & $9.33 \pm 1.53$ & $8.00 \pm 0.58$ \\
\hline 3 & nd & nd \\
\hline 4 & $12.33 \pm 1.53$ & $11.00 \pm 0.00$ \\
\hline 5 & $7.67 \pm 0.58$ & $7.00 \pm 0.00$ \\
\hline 6 & $11.67 \pm 0.58$ & $16.33 \pm 0.58$ \\
\hline 7 & $9.67 \pm 0.58$ & $8.67 \pm 0.58$ \\
\hline 8 & $9.00 \pm 0.00$ & $9.00 \pm 0.00$ \\
\hline 9 & $10.67 \pm 0.58$ & $13.33 \pm 1.15$ \\
\hline 10 & $10.33 \pm 0.58$ & $11.67 \pm 1.53$ \\
\hline 11 & $7.00 \pm 0.00$ & $6.33 \pm 0.58$ \\
\hline 12 & $7.67 \pm 0.58$ & $7.00 \pm 0.00$ \\
\hline 13 & $6.33 \pm 0.58$ & $6.67 \pm 0.58$ \\
\hline 14 & $8.00 \pm 0.00$ & $7.33 \pm 0.58$ \\
\hline 15 & $10.00 \pm 0.00$ & $12.00 \pm 0.00$ \\
\hline 16 & $30.00 \pm 0.00$ & $30.00 \pm 0.00$ \\
\hline 17 & $11.67 \pm 1.53$ & $10.33 \pm 1.15$ \\
\hline 18 & $30.00 \pm 0.00$ & $30.00 \pm 0.00$ \\
\hline 19 & $18.33 \pm 5.03$ & $12.67 \pm 1.15$ \\
\hline 20 & $10.33 \pm 0.58$ & $9.33 \pm 0.58$ \\
\hline 21 & $11.33 \pm 0.58$ & $16.00 \pm 0.00$ \\
\hline
\end{tabular}

Positive control: Chloramphenicol $(25 \mu \mathrm{g})$, S.l. Sarcina lutea; V.ch. No-01. Vibrio cholerae; nd, not determined.

\section{REFERENCES}

[1] Hernandez T, Canales M, Avila JG, et al. Ethnobotany and antibacterial activity of some plants used in tradicional medicine of Zapotitlán de las Salinas, Puebla (México). J Ethnopharmacol 2003; 88: 181-8.

[2] Arcina-Lozano CC, Liarca-Piña G, Lecoma-Uribe S, Gonzalez EM. El orégano: propiedades, composición y actividad biológica de sus componentes. Arch Latinoamer de Nutric 2004; 54: 1-20.

[3] Randrianalijaona JA, Ramanoelina PAR, Rasoarahona JRE, Gaydou EM. Seasonal and chemotype influences on the chemical composition of Lantana camara L. Essential oils from Madagascar. Anal Chim Acta 2005; 545: 46-52.

[4] Viljoen AM, Subramoney S, Vuuren SF, Baser KHC, Demirci B. The composition, geographical variation and antimicrobial activity of Lippia javanica leaf essential oils. J Ethnopharmacol 2005; 96: 271-7.

[5] Yang H, Ding C, Duan Y, Liu J. Variation of active constituents of an important Tibet folk medicine swertia mussotii Franch. Between artificially cultivated and naturally distributed. J Ethnopharmacol 2005; 98: 31-5.

[6] Perez-Alonso MJ, Velasco-Negueruela A, Pala-Paul J, Sanz J. Variantions in the essential oil composition of Artemisia pedemontana gathered in spain: chemotype camphor-1,8- cineole and chemotype davanone. Biochem Syst Ecol 2003; 31: 77-84.

[7] García E. Diversidad climática vegetal en México, Instituto de Geografía, UNAM, Mexico, 1988; pp. 16-25.

[8] Rzedowski J. Vegetación de México. México; Limusa 1978; p. 432.

[9] Valiente-Banuet A, Flores N, Verdú M, Dávila P. The chaparral vegetation in Mexico under non-mediterranean climate: convergence and Madrean-Tethyan hypotheses reconsidered. Am J Bot 1998; 85(10): 1398-408.

[10] Casas A, Valiente-Banuet A, Viveros JL, et al. Plant resources of the Tehucán-Cuicatlán Valley, Mexico. Econ Bot 2001; 55: 129 66.

[11] Hernandez T, Canales M, Caballero J, Duran A, Lira R. Analisis cuantitativo del conocimiento tradicional sobre plantas utilizadas para el tratamiento de enfermedades gastrointestinales en Zapotitlan de las Salinas, Puebla, Mexico. Interciencia 2005; 30(9): 52935 .

[12] Lopez-Galindo F, Muñoz-Iniestra D, Hernandez-Moreno M, SolerAburto A, Castillo-Lopez MC, Hernandez-Arzate I. Análisis integral de la toposecuencia y su influencia en la distribución de la vegetación y la degradación del suelo en la Subcuenca de Zapotitlán Salinas, Puebla. Bol Soc Geo Mex 2003; Tomo LVI, (1), 19-41.

[13] Vanden Berghe DA, Vlietinck AJ. Screening methods for antibacterial agents from higher plants, In: Dey P.M, Harborne J.B, Hostettman K, Eds. Methods in plant Biochemistry, Assay for Bioactivity, vol. 6. Academic Press, London, 1991; pp. 47-69.

[14] Rohlf FJ. Numerical taxonomy and multivariate análisis system (NTSYS) Versión 2.0, Manual. Applied Biostatistics Inc., USA 1997.

[15] Harborne JB. Recent advances in the ecological chemistry of plant terpenoids, In: Harborne J.B, Tomas-Barberan F.A, Eds. Ecological chemistry and biochemistry of plant terpenoids. Clarendon Press-Oxford, New York, 1991; pp. 399-426.

[16] Cimanga K, Kambu K, Tona L, et al. Correlation between chemical composition and antibacterial activity of essential oils of some aromatic medicinal plants growing in the Democratic Republic of Congo. J Ethnopharmacol 2002; 79: 213-20.

[17] Juven BJ, Kanner J, Schved F, Weisslowicz H. Factors that interact with the antibacterial action of thyme essential oil and its active constituents. J Appl Bacteriol 1994; 76: 626-31.

[18] Kim J, Marshall MR, Wei C. Antibacterial activity of some essential oil components against five foodborne pathogens. J Agric Food Chem 1995; 43: 2839-45.

[19] Knobloch L, Weigand H, Weis N, Schwarn HM, Vigenschow H. Action of terpenoids on energy metabolism. In: Brunke EJ, Ed. Progress in Essential Oil Research. USA; Walter de Gruyter 1985; pp. 429-448.

[20] Sivropoulou A, Papanicolaou E, Nikolaou C, Kokkini TL, Arsenakis M. Antimicrobial and cytotoxic activities of Origanum essential oils. J Agric Food Chem 1996; 44: 1202-5

(C) Hernández et al.; Licensee Bentham Open.

This is an open access article licensed under the terms of the Creative Commons Attribution Non-Commercial License (http://creativecommons.org/licenses/by$\mathrm{nc} / 3.0 /$ ) which permits unrestricted, non-commercial use, distribution and reproduction in any medium, provided the work is properly cited. 